\title{
Editorial
}

\section{Internacionalização do ensino superior}

O termo internacionalização refere-se às trocas de conhecimento entre as nações e às relações que daí resultam. À primeira vista, parece tratar-se de um assunto contemporâneo, pois vivemos a era da tecnologia da informação e, consequentemente, o conhecimento está em rede, o que supõe sua disseminação. Entretanto, o caráter internacional das universidades está presente desde a Idade Média nas primeiras escolas europeias, cujos professores e estudantes de diferentes lugares e países constituíam comunidades internacionais, as quais se aliavam com a finalidade de compartilhar saberes.

O caráter universal do conhecimento está na multiplicidade de valores e de opiniões que se experimentam nas IES, e por esse motivo o intercâmbio de pesquisadores, acadêmicos e professores intensifica as ligações internacionais, estabelecendo e fortalecendo redes do conhecimento universal.

Essa mobilidade é estimulada pelas próprias IES e pelo Ministério da Educação, com programas como o Ciências sem Fronteira. Ocorre também a partir de ações da Coordenação de Aperfeiçoamento de Pessoal de Nível Superior (Capes) e de outras instituições de diversas naturezas, que oferecem bolsas de estudo para estudantes de graduação e de pós-graduação.

Esse compartilhamento de conhecimentos entre as IES, no âmbito internacional, assegura o avanço da qualidade dos programas de ensino, pesquisa e extensão.

Há de se chegar a um patamar em que a internacionalização seja um processo pleno, não limitado ao envio de pessoas da academia sem comprometimento de cooperação interinstitucional, mas, sim, manifestando vínculo acadêmico, científico e tecnológico, cujo objetivo seja um processo transformador dos sistemas de educação superior, promovendo um comparativo de questões científicas, socioeconômicas, ambientais e de atitudes presentes no cenário contemporâneo. Somente dessa forma firmam-se trocas e experiências construtivas entre as instituições.

Enfim, é ainda necessária uma discussão comprometida, em todos os âmbitos da academia, com a participação dos acadêmicos, dos colegiados e das diversas esferas das reitorias, para que realmente essa cooperação internacional não ocorra de forma pontual, descompromissada e avulsa, mas que faça parte da vida acadêmica, proporcionando a troca constante de informações produzidas, socializando conhecimentos - com vistas ao crescimento - , e dando crédito aos valores universais. 